\title{
Foliar fungicide application as management strategie to minimize the growing threat of yellow rust on wheat in Portugal
}

\author{
Conceição Gomes, Ana Sofia Almeida, José Coutinho, Rita Costa, Nuno Pinheiro, João Coco, \\ Armindo Costa, Ana Sofia Bagulho, Benvindo Maçãs
}

INIAV - National Institute for Agrarian and Veterinarian Research, Estrada Gil Vaz, Ap. 6, 7350-901 Elvas, Portugal

\section{A B S T R A C T}

\begin{abstract}
Yellow rust caused by Puccinia striiformis f. sp. tritici, is a foliar wheat disease that cause significant yield losses in Portuguese bread and durum wheat yield, mainly in recent years. The strategies to disease control include cultural practices (crop rotation, use of balanced fertilizers, framework of planting dates), use of resistant varieties and fungicide application. The concern of modern plant breeding has been the improvement of new varieties with escape behavior to diseases and/or genetic resistance, but currently, the use of chemical produts offers a pratical and rapid response solution to combat rust outbreaks. In the present study, field experiments were conducted from $2013 / 2014$ to 2016/2017 growing seasons to evaluate: 1) resistance levels against yellow rust in some bread and durum wheat varieties widely used by Portuguese farmers; 2) the opportunity of application of fungicide in the control of Puccinia striiformis in two stages of plant development; 3) gains obtained in each situation in yield and thousand kernel weight (TKW) compared to the control without fungicide application. This study allows to conclude that the need to use fungicide sprays it 's related not only on the carry over of rust inoculum in crop, but also of the races/strains of $P$. striiformis occurring in a region, the crop growth stage at time of symptom appearance and on variety level of resistance.
\end{abstract}

Keywords: Bread and Durum wheat; Yellow rust; Genetic response; Resistance genes

\section{INTRODUCTION}

Bread wheat (T. aestivum) and durum wheat (T. durum) are important cereal crops in many parts of the world, in terms of global food production and socio-economic conjunture.

According to some reports, main current challenges facing global wheat production are the prevailling climate changes, increasing drought/water shortage, decreased soil fertility, declining supply and increasing costs of fertilizers, raising demand for bio-fuel (Solh et al., 2012) and ever-growing threat of new virulence of diseases whose effects on yield potentials and quality wheat losses can not be neglicted.

Among foliar diseases affecting wheat, those caused by fungi from genus Puccinia (P. striiformis, yellow/stripe rust, $P$. triticina, brown/leaf rust and $P$. graminis, black/stem rust) have historically induce major crop losses, because of their widespread prevalence and airborne which allows them to be transported by wind over long distances. However extent of losses, in part, dependent upon the level of susceptibility or resistance of wheat varieties grown by farmers, weather conditions, infection time, disease development rate and disease duration (Chen, 2005).

The use of chemical produts offers a pratical and rapid response solution to combat rusts outbreaks. There are several fungicides with varying efficacies that, when used in diferent phenological plant stages and according to the degree of fungus severity/variety susceptibility, can protect the crop against diseases. However, they are polluting, expensive and may promote the development of fungus resistance to their active substances. Contrary to application of crop protection fungicides, growing resistant varieties is the most eficient, economical and friendly approach strategy to minimize yield losses due to diseases.

Several international wheat breeding programs have been developing high yielding and widely adapted wheat

\footnotetext{
${ }^{*}$ Corresponding author:

Conceição Gomes, INIAV - National Institute for Agrarian and Veterinarian Research, Estrada Gil Vaz, Ap. 6, 7350-901 Elvas, Portugal.

E-mail: conceicao.gomes@iniav.pt
}

Received: 12 March 2018; Accepted: 29 August 2018 
germoplasm with resistance/tolerance to rusts, but the pathogens developed new virulent pathotypes (strains or races) that overcome the most broadly advanced genes and the resistance of these varieties are short-lived.

Particularly in the last decades, new aggressive strains of Puccinia striiformis $\mathrm{f}$. sp. tritici were widely spread in diferente areas and environments favoring disease epidemics. In Portugal, since 2014, yellow rust has high prevalence requiring the farmers to have a timely control, with the application of fungicides, to ensure final grain yield.

The present paper begins with an overview of genetic breeding to yellow rust resistance and a brief description about the current worldwide status of agressiviness of the fungus $P$. striiformis, with an impact in the European and Portuguese cases. Afterwards results of a pratical disease management carried out from 2013/2014 to 2016/2017 grown seasons are presented, aiming to acess the gains achieved in severity control of yellow rust and in yield and thousand kernel weight (TKW) of diferent wheat species (bread and durum), with a fungicide applied in distinct stages of phenology. Results obtained allow: a) to improve information about the degree of resistance against yellow rust in bread and durum wheat varieties widely used by portuguese farmers; $b$ ) to check that foliar fungicide reduced the wheat yield and TKW (as the main yield component) losses due to disease, in comparison to the control without fungicide application; $\mathrm{c}$ ) to show that the extent of fungicide protection depends on: the disease pressure; the level of genetic variety resistance (susceptible, moderate or resistant); the occurence timing of the pathogenic infection in relation with plant growth stage (e.g. when disease pressure reaches threshold level between flag leaf initiation and ear emergence it is essencial to apply fungicide).

\section{Genetic breeding to yellow rust resistance: an overview}

Yellow rust has been reported as a devastating disease with repeat cases of worldwide invasions, possible due to: the transboundary nature of the pathogen, that allows a long distance migration capacity; the adaptation to different meteorological conditions and the high variation from avirulence to virulence via somatic and assexual recombination, which enable to increase genetic variability resulting in evolution of new agressive races, strains or pathotypes that breakdown resistance genes. Moreover, the recent discovery of the Berberis spp. as a sexual host (which let the pathogen to increase its population diversity) came to end with the idea that this fungus reproduced only asexually (Jin et al., 2010, cit. by Rodriguez-Algaba, 2017).

The research for yellow rust resistance has already led to the identification and characterization of about seventy resistant genes; a number of them, inserted into comercial wheat varieties, have been mapped. Most are race-specificgene (Qamar et al., 2012), effective against some, but not all, rust races, provided a so-called qualitative or vertical resistance. It is general governed by one major resistance gene, can be detected at the seedling stage of host plant and follows a host-pathogen interaction consistent with the well-described gene-for-gene hypothesis (Sorensen et al., 2014). This broad of resistance depends on a specific genetic interaction between host resistance genes $(\mathrm{R})$ and pathogen avirulence (Avr): in plants, $R$ genes predominantly encode nucleotide-binding and leucine-rich-repeatproteins (NLR) wich acts as imune receptors to recognize pathogen effector proteins delivered into host cells during infection (Perlyannon et al., 2017). However this resistance is ephemeral in nature, because new virulence races of P. striiformis are continously evolving through a single step mutation, recombination or migration (Qamar et al., 2012). The average lifetime of these genes is short, not more than five years (Silpatrick, 1975, cited by Safavi, 2015). Due to its inheritance and effective disease control in the absence of virulent pathogen races, race-specific-genes have been widely used by CIMMYT wheat breeding to rust resistance during 1965-1985 (Hussan et al., 2017) and they are very common in European wheat cultivars (Sorensen et al., 2014).

To resolve the partial resistance conferred by race specific $\mathrm{R}$ genes and it propensity to breakdow induced by variations in pathogen Avr genes, has been suggested the utilization of cultivars mixtures as a way to create intrafield diversity, however it has rarely been adopted on a large scale in intensive crop production, because it leads to some complications arising from mixing cultivars with diferente cropping requiriments (Vallavieille-Pope et al., 2012).

Accordingly, in the last decades, breeders are reviewing their breeding strategy and opted to group minor genes with major genes to develop rust resistance. This alternative resistance called quantitative, horizontal, race-non-specific, durable, adult plants or slow rusting resistance is polygenic and it is known to be long lasting, effective against several virulent pathotypes of a pathogen species in the field. In wheat this kind of resistance arise only at adult plant development, where it lends to become more and more effective as the host plant mature (Sorensen et al., 2014). Often varieties may show vulnerability at seedling stage but adult plant stage show low disease incidence (Hussain et al., 2017).

The quantitative resistance has been much less used in breeding programs, mainly because its screening and breeding are more complex and more time consuming (Laetitia et al., 2017) and require a knowledge of virulence 
rust pathogen and your infection type on wheat (Gangwar et al., 2017); for to reach effectiveness it's importante to know the interactions that will arise with the combination of different resistance genes and identify avirulence genes which can be achieved through conventional breeding aproches, marker-assisted selection based on cloned genes sequences or through the deployment of resistance genes cassettes in which multiple cloned genes may be combined in a single locus (Perlyannan et al., 2017).

It is know that the use of varieties with different resistance genes, at the regional level, would prevent the selection and uniform spread of a specific pathotype; on a large scale, could help to avoid the rapid propagation of new races (as was observed for the highly aggressive temperature-adapted P. striiformis race, e.g.,).

\section{A brief description of the current worldwide status of Puccinia striiformis f. sp. tritici aggressiviness, on a European and Portuguese level}

The high genetic and genotypic diversity, recombinant population structure, high sexual reprodution capacity and abundance of alternate host (Berberis spp.) suggested the Himalayan and near-Himalayan region (Nepal, Pakistan and China) as a presumable centre of origin of Puccinia striiformis (Shajid et al., 2015). The pathogen is distributed worldwide due to its long distance dispersal across continents by nature and human means and its rapid local adaptation via stepwise evolution. In Europe, America and Australia, the populational struture of the fungus presents a clonality, possible due to its monotopic origin.

In the beginning of $20^{\text {th }}$ century the pathogen was reported for the first time in North and South America, most likely spreading from NW Europe. It was unintentionally transported to Australia in 1979 from NW Europe on clothing of international air-travelers. The South African population showed to be genetically related to populations in Mediterranean regions and Central Asia (Walter et al., 2016). Stubbs (1985) point out that the virulence evolution of $P$. striiformis it is also due to the international exchange of host resistances, which contributed to microevolution of the fungus gradually exchanged into macroevolution. For another words, Sajid et al. (2017) said that a large scale deployment of host varieties with narrow genetic background for disease resistance have contributed to cause the acquisition of virulence at a regional and continental scales.

Until recently the rust population in Europe, although diverse, has been genetically very similar. But at last decade the overall picture on yellow rust has changed: the old races have been replaced by new and more virulent pathotypes that overcomed wheat (bread and durum) and triticale resistant genes. The Warrior/Ambition race, first described during 2009/2010 season in United Kingdom, Germany, Denmark, France and Scandinavia, being next year detected in Spain where several epidemics events resulted in serious crop damage and yield losses (Vergara-Diaz et al., 2015). Morocco confirmed this race in 2013 and subsequently Algeria and Turkey in 2014 (Hodson, 2015).

The Kranish race appeared in 2011. It has a broad virulence spectra and cause disease epidemics in many European countries (Sweden, Scandinavia and Poland).

Allen-Stevens (2017) believes that Warrior and Kranish are originated from the pathogen centre of diversity in Himalayas, because several genotyping works has confirmed that they are similar with isolates found in that region.

After 2013, a new race named Warrior (-) will replace Warrior and dominates the pathogenic population across Europe and Western Asia. Hovmoller (2017) cited by Allen-Stevens (2017) referred its similarity "that's related but not the same, although we believe it's from the same source region".

Presently there are other developments in rust populations which require scientists and growers keeping an eye on: the wide spread of two new triticale races and two new exotics wheat races.

The triticale agressive races are named Triticale 2006 and Triticale 2015 (that wiped out many triticale crops grown in many countries around the Baltic sea), and both have caused up to $100 \%$ yield losses in susceptible varieties, which were not treated with fungicides (Hovmoller et al., 2017). The exotic wheat races are two aggressives and high temperature adapted strains, $\mathrm{PstS}_{1}$ and $\mathrm{PstS}_{2}$, that are causing considerable problems in North America, Middle East and Western Australia, places where yellow rust has not really been a problem before, because they were considered too warm (Allen-Stevens, 2017). In 2000, $\mathrm{Pst}_{2}$ was reported in NW Europe with aggressiveness and strong differentiation from local P. striiformis populations, but did not have an adverse economic impact, because most European wheat varieties were resistant to this strain (Walter et al., 2016).

Hovmoller cited by Allen-Stevens (2017), believes that changes in climate and growth patterns have combined to create a perfect storm and the ideal environment for yellow rust to thrive. He said: "right across Europe, wheat crops are now established earlier in automn, providing a green bridge for the pathogen. We've also seen a sucession of mild automns-if the night time temperature in September 
and October is around $10^{\circ} \mathrm{C}$ and you have a dew during most of those nighs, you couldn't ask for more perfect conditions for yellow rust establish".

In Portugal, the fungus $P$. striiformis was absent during around twenty years, but since 2013 growing season has become a largest biotic limitation to wheat (initially only in T. aestivum, but in subsequent years as well in T. durum) and also to triticale production. The presence of pathogen has been reported either on varieties widely used in Portuguese agriculture but also on national plant breeding program: exotic lines and cultivars from international breeding programs and lines/varieties resulting from artificial hybridization using as parents international and national germplasm.

However, in the first two years the fungus severity was great in susceptible germplasm but in 2016/2017 growing season the pathogen aggressiveness was lower. This could be explained by climatic variables, especially winter/spring temperatures, which reduced the viability of the inoculum, and by farmers performance, who when applying fungicide as a preventive measure could control the primary infections.

\section{Presence of Puccinia striiformis f. sp. tritici in Portugal: a study site}

The study was conduted from 2013/2014 to 2016/2017 growing seasons at experimental fields of National Plant Breeding Station at Elvas, Portugal (lat. - $38^{\circ} 53^{\prime} 15^{\prime \prime}$ $\mathrm{N}$; long. - $07^{\circ} 08^{\prime} 42^{\prime \prime} \mathrm{W}$; alt. - $\left.219 \mathrm{~m}\right)$, under irrigated conditions.

Study main goals were to get information about: 1) resistance levels against yellow rust in some bread and durum wheat varieties widely used by Portuguese farmers; 2) to evaluate the opportunity of application of fungicide in the control of Puccinia striiformis in two stages of plant development; 3) to quantify gains obtained in each situation in yield and thousand kernel weight (TKW) compared to the control without fungicide application.

\section{MATERIAL AND METHODS}

The experiment was laid down as a split-split plot design with three replications. The area of individual plot was $6 \mathrm{~m}^{2}$. Field trial was set up under naturally occurring inoculum of P. striiformis.

In each year, diverse varieties (bread and durum wheat) were used. It is always a concern to include in on-going research trials varieties of different provenance, with different genetic background of resistance to rust and widely sown by Portuguese farmers (Table 1).

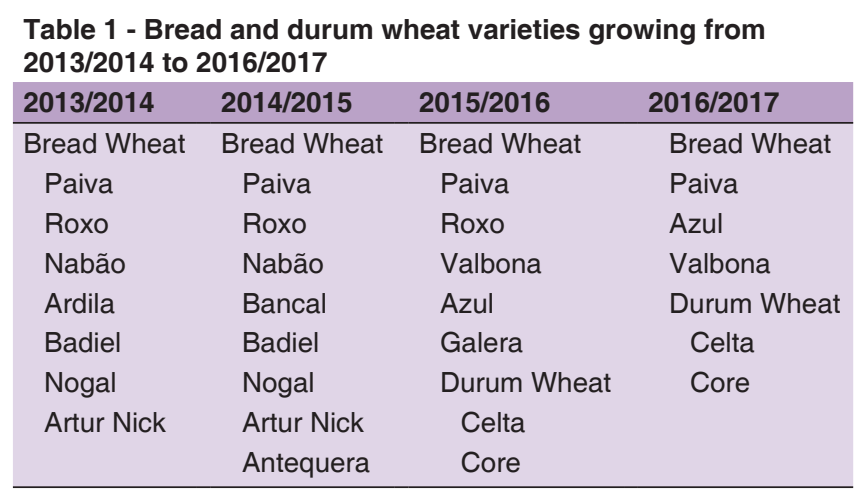

The seed density was always 350 grains $/ \mathrm{m}^{2}$, based on TKW of each variety.

Sowing date varied with growing season: 2013/2014 - 10 December 2013; 2014/2015 - 4 December 2014; 2015/2016 - 1 December 2015; 2016/2017 _ 10 January 2017.

The trial included plots where fungicide Aviator (Bixafen + Protioconazol) was sprayed one (1TT) or two times (2T'T), aligned with wheat growth stages, and a plot without treatment $\left(0 \mathrm{~T}^{\circ} \mathrm{T}\right)$ as control. According with Zadok's stages (1972), treatment with one foliar application of fungicide was carried out at GS34 (jointing) and for treatment with two foliar sprays, fungicide was applied at GS34 and at GS44 (booting). Fungicide was applied with the recommended dose rate $(1,250 \mathrm{l} / \mathrm{ha})$.

A sprinkler irrigation system was used to ensure plants water comfort and to promote a dew formation on plant surfaces in order to provide favorable conditions for infection by pathogen spores.

The disease severity was assessed at heading (GS55) on the flag leaf, which contributes the most to grain yield (Peppler et al., 2005), based on percentage of green leaf area affected along with the variety response, using modified Cobb's scale; these scores are then converted to a coefficient of infection (CI) by multiplying severity by an assigned constant value for the variety response, according to the table below (Stubbs et al., 1986).

\begin{tabular}{lcc}
$\begin{array}{l}\text { Field } \\
\text { score }\end{array}$ & $\begin{array}{c}\text { Disease severity }(\%) \mathbf{x} \\
\text { variety response }\end{array}$ & $\begin{array}{c}\text { Coefficient } \\
\text { Infection }(\mathbf{C l})\end{array}$ \\
\hline $\mathrm{R}$ & $1 \times 0.2$ & 0.2 \\
$5 \mathrm{MR}$ & $5 \times 0.4$ & 2.0 \\
$10 \mathrm{MS}$ & $10 \times 0.8$ & 8.0 \\
$20 \mathrm{~S}$ & $20 \times 1.0$ & 20.0 \\
\hline
\end{tabular}

Harvest took place at plant maturity (mid-late June); total yield was expressed as $\mathrm{kg} / \mathrm{ha}$ and thousand kernel weight as $\mathrm{g}$. The potencial reduction of yield loss (in the absence of foliar spray of fungicide) was calculated as yield difference 
between fungicide sprayed and control treatment for each variety expressed in percentage of sprayed plots, as Eq. (1):

Yield loss $(\%)=[(Y s p-Y n s p) / Y s p] \times 100$

Where, Ysp and Ynsp indicate grain yield under sprayed and no-sprayed conditions, respectively.

Statistical analysis was performed on SPSS programme (IBM, version 17.0). ANOVA $(\mathrm{P}<0.05)$ was performed for each year, separately, in order to explore specific effects of variety, treatment and treatment $x$ variety interaction within each year.

Weather data for the study seasons were taken from an automated weather station located at the study site. Precipitation and minimum temperature data are shown, since they are the most importante weather parameters affecting epidemic of yellow rust. Rain can disperse spores to spread the disease, because raindrops release urediniospores either by direct impact or by splashing. Furthermore after rains, high moisture in the air and soil often creates drew providing favorable conditions for leads to stronger adhesion of spores to the leaves and increase infection frequency. Minimum temperature, but not marginal temperature, play a more critical role on sporulation, spore germination and spores survival than maximum or average temperatures.

According Chen (2005), night temperatures play a more critical role than daytime temperatures. Both dew formation and low temperatures occurs together most frequently at night, and therefore infections are more likely to occur at this period. The use of daily average and maximum temperatures is misleading, because it doesn't specify the period of time with temperatures that allows infection.

The weather data presented in our study focus on the rainfall and minimum temperatures recorded at three periods of ten days in January, February, March and April, because natural outbreak of yellow rust at Elvas occurs mainly between February and April. For each ten days period, the number of days that the minimum temperature was $\geq$ than $5^{\circ} \mathrm{C}$ was presented.

\section{RESULTS}

\section{1 - Weather conditions occuring at Elvas during the four years of testing}

The first four months of 2014 were wet with milder minimum temperatures (Fig 1). During this period (except March) there were always occurrence of rainfall, high relative humidity and optimum temperature for germination and establishment of colonies of yellow rust.

In 2013/2014 season, the first symptoms of yellow rust were recorded in bread wheat in February. In March the disease severity was already considerable, and in April the weather conditions were conducive to secondary infections and the disease spread throughout several regions.

In 2015, January and February were months with lower precipitation and humidity and with minimum temperatures falling below $5^{\circ} \mathrm{C}$ with frosts. However, in March and April, rainfall brought periods of cloudiness and moisture favorable to fungus development, boosted by an increase in the number of days with temperatures above $5^{\circ} \mathrm{C}$ (Fig 2 ).

Early disease symptoms were only detected during March, with a peak of infection between April and May, not only in bread wheat but also in triticale, species that until today were resistant.

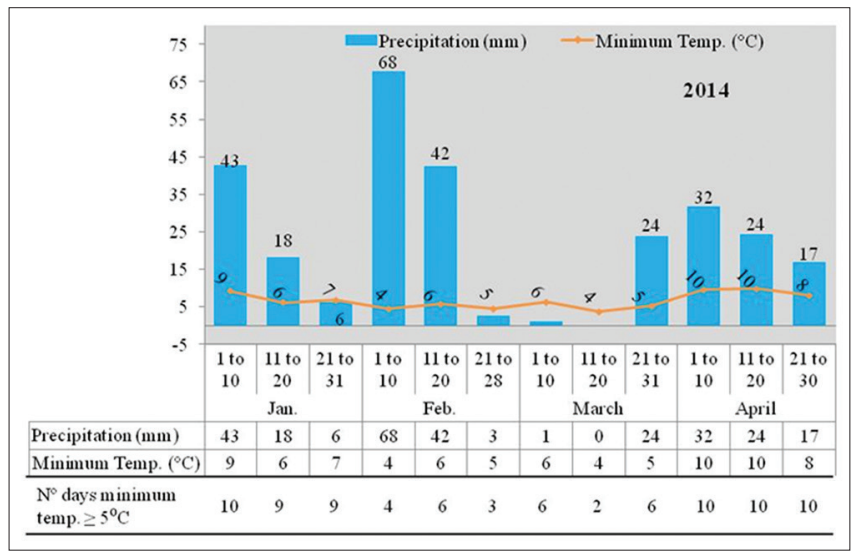

Fig 1. Precipitation $(\mathrm{mm})$, minimum temperature $\left({ }^{\circ} \mathrm{C}\right)$ and $\mathrm{n}^{\circ}$ of days with minimum temperature $\geq 5^{\circ} \mathrm{C}$ for periods of ten days on January, February, March and April of 2014.

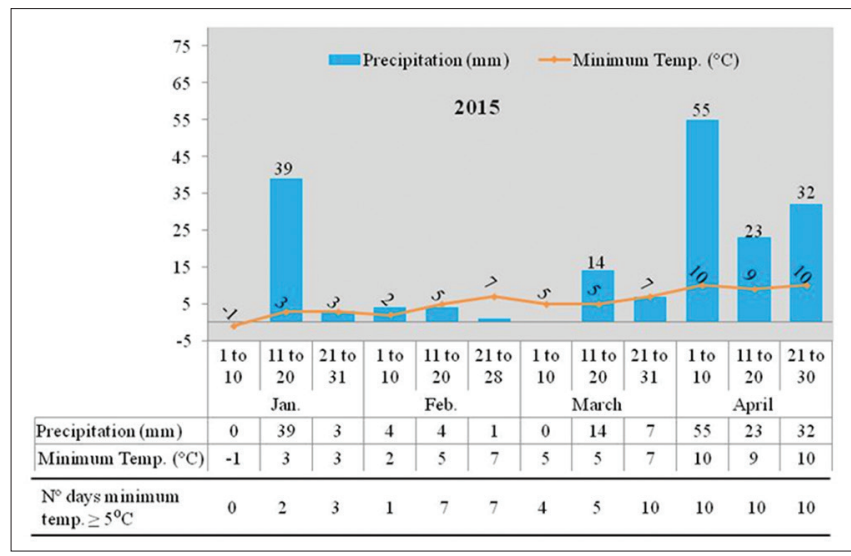

Fig 2. Precipitation $(\mathrm{mm})$, minimum temperature $\left({ }^{\circ} \mathrm{C}\right)$ and $\mathrm{n}^{\circ}$ of days with minimum temperature $\geq 5^{\circ} \mathrm{C}$ for periods of ten days on January, February, March and April of 2015. 
The winter and spring months of 2016 were wet, characterized by the periodic occurrence of precipitation. Regarding minimum temperatures, they were mild for the time of year, ranging from $5^{\circ} \mathrm{C}$ to $9^{\circ} \mathrm{C}$ on most days (Fig 3).

Metereological conditions of 2015/2016 growing season were optimal for the emergence of primary infections of P. striiformis at the end of February on bread wheat, triticale (observed in other field trials, data not shown) and, for the first time, also on durum wheat. The continuation of this favorable weather boosted the development of a series of secondary infections.

The climatic pattern of 2016/2017 was different: weak and erratic distribution of rain during winter and spring months; occurrence of a cold front in the second half of January which led to lower temperatures, including frosts; February precipitation was not enough either for normal plant development either for relative humidity conditions although mild minimum temperatures (Fig 4).

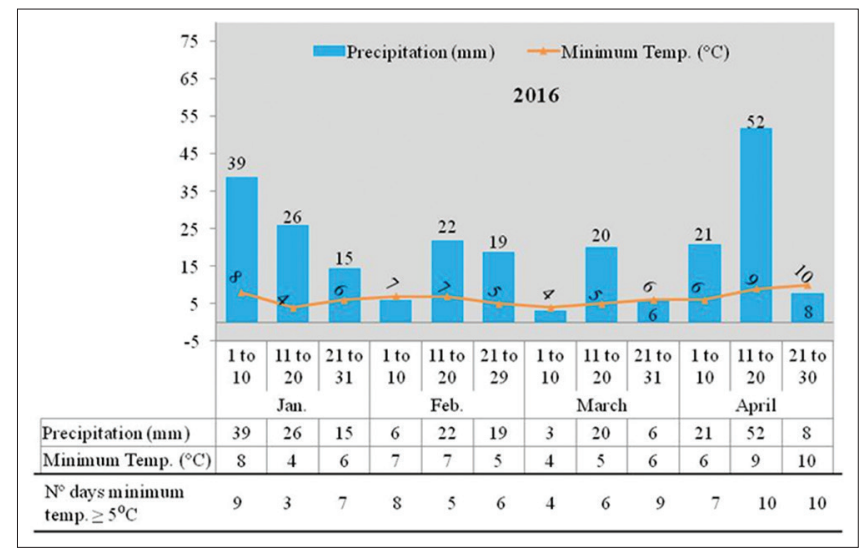

Fig 3. Precipitation $(\mathrm{mm})$, minimum temperature $\left({ }^{\circ} \mathrm{C}\right)$ and $n^{\circ}$ of days with minimum temperature $\geq 5^{\circ} \mathrm{C}$ for periods of ten days on January, February, March and April of 2016.

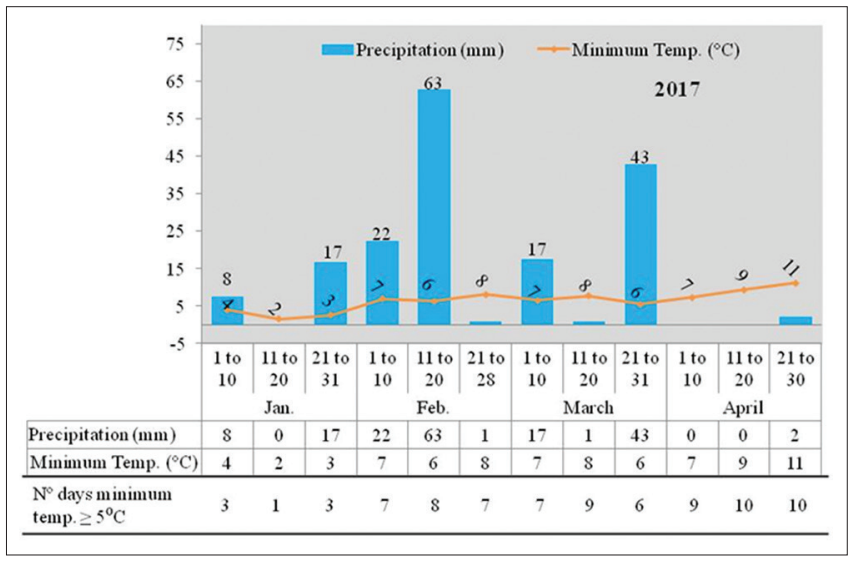

Fig 4. Precipitation $(\mathrm{mm})$, minimum temperature $\left({ }^{\circ} \mathrm{C}\right)$ and $\mathrm{n}^{\circ}$ of days with minimum temperature $\geq 5^{\circ} \mathrm{C}$ for periods of ten days on January, February, March and April of 2017.
Towards this scenario of low rain and both minimum temperature and moisture disadvantaged for the germination and establishment of colonies of fungus, 2016/2017 growing season was characterized by the nonoccurrence of P. striiformis.

\section{2-Disease severity, yield and thousand kernel weight of varieties for the four years studied}

The effectiveness of a fungicide should not only be determined in terms of disease control but also at the level of increases in final crop yield.

Varieties sown in 2013/2014 showed differences related to resistance behavior to fungus (Fig 5). Badiel and Nabão were susceptible (CI 360 , in the non-treatment situation) and the symptoms of $P$. striiformis were visible immediately after tillering (GS25), only with two fungicide applications the control of disease progression was achieved. Ardila and Paiva showed moderate levels of resistance and one treatment at GS34 was enough. Roxo, Nogal and Artur Nick denoted a slow rusting resistance, and consequently the use of preventive treatment may prevent potential infections.

Data presented in Table I show that yield and TKW were high significantly affected $(P \leq 0.1 \%)$ by treatment and variety, as well as by treatment $x$ variety interaction. The least productive varieties in the non-treatment situation were the most susceptibles one (Badiel and Nabão) and two fungicide applications were efficient allowing an increase in production of $77 \%$ and $69 \%$, respectively. For remaining varieties that express a moderate and/or slow rusting resistance behaviour, when reductions obtained with one or two treatments are compared it is confirmed that only one fungicide application at GS34 was justifiable.

The following growing season (2014/2015), higher aggressiveness of $P$. striiformis was noted on susceptible varieties (Badiel, Nabão and Bancal) and on Nogal

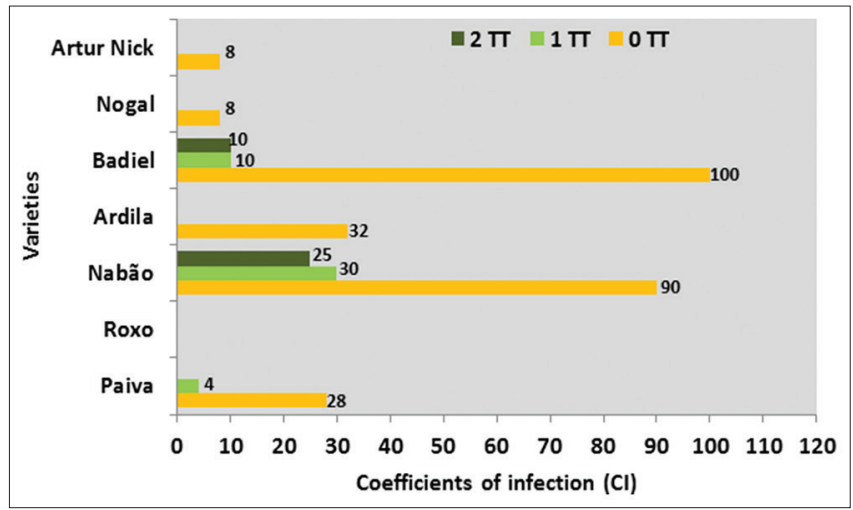

Fig 5. Coefficient of infection and varieties response to fungicide treatments in 2013/2014 growing season. 
(genotype that in the previous year had a tolerance behaviour) when no fungicide was applied (Fig 6). For these genotypes two treatments were necessary, including for Nogal and even so, Bancal continued with symptoms in ear and on $40 \%$ of foliar area. Roxo, Artur Nick Antequera and Paiva with CI values between 0 and 5 denoted some genetic resistance.

Yield and TKW data at this growing season (Table II) were higher than in the previous season without treatment (OT'T) due to the occorrence of a wetter spring with milder temperatures (minimum and maximum). ANOVA results showed a high significant effect of treatment, variety and treatment $\mathrm{x}$ variety interaction $(P \leq 0.1 \%)$ to all parameters. Over, for cultivars with lows levels of resistance (CI)60), the reduction of yield and TKW losses was higher when two treatments were performed; it is interesting to note that if one decides to apply fungicide twice on Nogal and Paiva, yield increases $8 \%$ over the untreated, but in Paiva this addition is related to its potencial genetic for increase the number of grains (data not shown) and not by grain weight. For Roxo, Artur Nick and Antequera the disease control is unnecessary.

Table 1: Yield (kg/ha) and TKW (g), and corresponding gains between treatments (0/TT, 1TT, 2TT) during 2013/2014 growing season

\begin{tabular}{|c|c|c|c|c|c|c|c|c|c|c|}
\hline \multirow[t]{2}{*}{ Variety } & \multicolumn{5}{|c|}{ Yield (kg/ha) } & \multicolumn{5}{|c|}{ TKW (g) } \\
\hline & OTT & 1TT & $\begin{array}{l}\text { Reduction (\%) } \\
\text { of yield loss }\end{array}$ & 2TT & $\begin{array}{l}\text { Reduction (\%) } \\
\text { of yield loss }\end{array}$ & OTT & 1TT & $\begin{array}{l}\text { Reduction (\%) } \\
\text { of TKW loss }\end{array}$ & 2TT & $\begin{array}{c}\text { Reduction (\%) } \\
\text { of TKW loss }\end{array}$ \\
\hline Ardila & 2312 & 3278 & 29 & 3326 & 30 & 25.33 & 28.91 & 12 & 31.17 & 19 \\
\hline Nogal & 3706 & 4918 & 25 & 5096 & 27 & 27.33 & 30.63 & 11 & 31.56 & 13 \\
\hline Nabão & 1528 & 3965 & 61 & 4898 & 69 & 22.67 & 27.31 & 17 & 29.29 & 23 \\
\hline Badiel & 1167 & 4141 & 72 & 4977 & 77 & 24.00 & 35.60 & 33 & 37.39 & 36 \\
\hline Roxo & 4739 & 5327 & 11 & 5375 & 12 & 29.33 & 33.81 & 13 & 34.58 & 15 \\
\hline Artur NicK & 3439 & 4189 & 18 & 4467 & 23 & 29.00 & 34.18 & 15 & 34.59 & 16 \\
\hline Paiva & 4744 & 5654 & 16 & 5883 & 19 & 37.67 & 40.10 & 6 & 42.57 & 12 \\
\hline Average & 3091 & 4496 & & 4860 & & 27.90 & 32.93 & & 34.45 & \\
\hline $\begin{array}{l}\text { Standard } \\
\text { deviation }\end{array}$ & 1454.81 & 836.24 & & 805.15 & & 4.97 & 4.36 & & 4.48 & \\
\hline CV (\%) & 47.07 & 18.60 & & 16.57 & & 17.81 & 13.24 & & 13.00 & \\
\hline Signif. TT & $* * *$ & & & & & $\star * *$ & & & & \\
\hline Signif. Var. & $* * *$ & & & & & $* * *$ & & & & \\
\hline Signif TT X Var. & $\star \star \star *$ & & & & & $\star \star \star *$ & & & & \\
\hline
\end{tabular}

stand for significant at the $0.1 \%$ level of probability

Table 2: Yield (kg/ha) and TKW (g), and corresponding gains between treatments (0/TT, 1TT, 2TT) during 2014/2015 growing season

\begin{tabular}{|c|c|c|c|c|c|c|c|c|c|c|}
\hline \multirow[t]{2}{*}{ Variety } & \multicolumn{5}{|c|}{ Yield (kg/ha) } & \multicolumn{5}{|c|}{ TKW (g) } \\
\hline & OTT & 1TT & $\begin{array}{c}\text { Reduction } \\
(\%) \text { of } \\
\text { yield loss } \\
\end{array}$ & 2TT & $\begin{array}{c}\text { Reduction } \\
(\%) \text { of } \\
\text { yield loss } \\
\end{array}$ & OTT & 1TT & $\begin{array}{c}\text { Reduction } \\
(\%) \text { of TKW } \\
\text { loss }\end{array}$ & 2TT & $\begin{array}{c}\text { Reduction } \\
(\%) \text { of } \\
\text { TKW loss }\end{array}$ \\
\hline Bancal & 2446 & 3763 & 35 & 4781 & 49 & 37.77 & 42.93 & 12 & 46.93 & 20 \\
\hline Nogal & 4748 & 5070 & 6 & 5149 & 8 & 31.47 & 32.87 & 4 & 31.50 & 0 \\
\hline Nabão & 4387 & 5195 & 16 & 5365 & 18 & 28.00 & 30.97 & 10 & 32.77 & 15 \\
\hline Badiel & 4788 & 6114 & 22 & 6610 & 28 & 36.40 & 40.40 & 10 & 42.87 & 15 \\
\hline Roxo & 4846 & 4442 & -9 & 4621 & -5 & 39.97 & 39.73 & -1 & 41.33 & 3 \\
\hline Artur NicK & 6554 & 6521 & -1 & 6686 & 2 & 39.23 & 39.00 & -1 & 40.57 & 3 \\
\hline Antequera & 5421 & 5447 & 0 & 5496 & 1 & 43.00 & 43.43 & 1 & 44.53 & 3 \\
\hline Paiva & 6181 & 6466 & 4 & 6719 & 8 & 45.40 & 45.47 & 0 & 44.43 & -2 \\
\hline Average & 4922 & 5377 & & 5678 & & 37.66 & 39.35 & & 40.62 & \\
\hline $\begin{array}{l}\text { Standard } \\
\text { deviation }\end{array}$ & 1251.81 & 974.44 & & 854.50 & & 6.18 & $5, .6$ & & 5.39 & \\
\hline CV (\%) & 25.44 & $18, .2$ & & 15.05 & & 16.41 & 13.37 & & 13.27 & \\
\hline Signif. TT & $* \star *$ & & & & & $\star * *$ & & & & \\
\hline Signif. Var. & $* * *$ & & & & & $\star \star \star *$ & & & & \\
\hline Signif TT X Var. & $* * *$ & & & & & $* * *$ & & & & \\
\hline
\end{tabular}

stand for significant at the $0.1 \%$ level of probability 
Due to the optimal winter and spring weather conditions of 2015/2016 and the inoculum severity, the emergence of primary infections of $P$. striiformis were recorded at February on bread and durum wheat. The possibility that the pathogen had increased its virulence was noted, inclusive, on some varieties of triticale where the severity

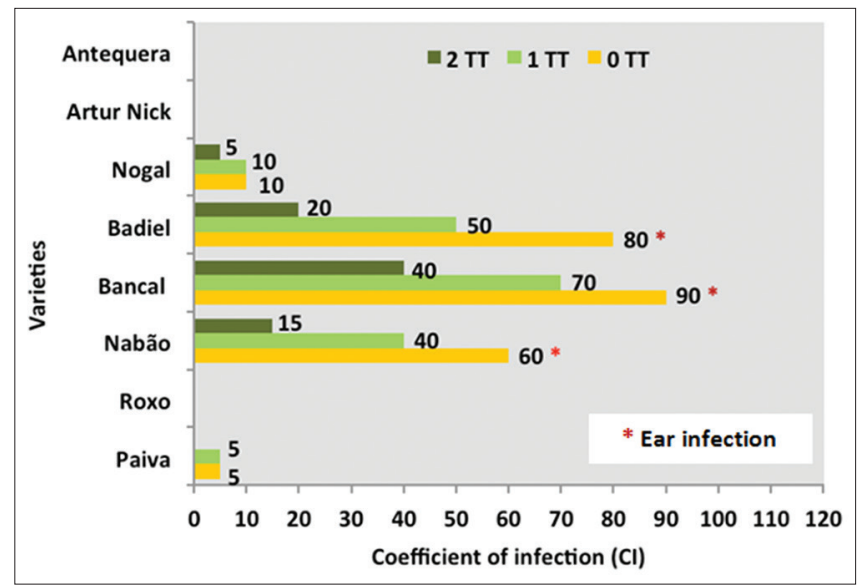

Fig 6. Coefficient of infection and varieties response to fungicide treatments in 2014/2015 growing season. attack was more intense. The genetic resistance of Roxo and Paiva was overcomed and presented symptoms at ear level (gone from moderately susceptible to a typical susceptibility symptomatology), with durum wheat Celta and Core having fungus symptoms (Fig 7). Two treatments were necessary whenever the symptoms were located at

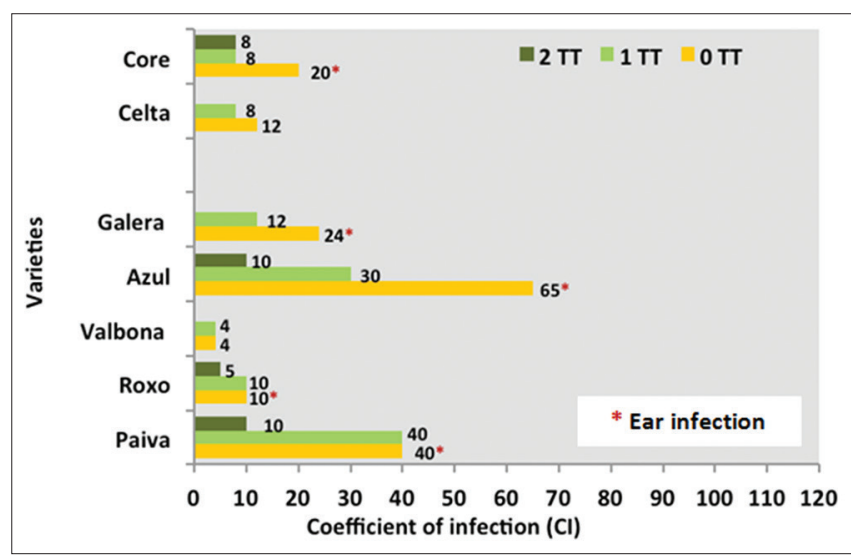

Fig 7. Coefficient of infection and varieties response to fungicide treatments in 2015/2016 growing season.

Table 3: Yield (kg/ha) and TKW (g), and corresponding gains between treatments (0/TT, 1TT, 2TT) during 2015/2016 growing season

\begin{tabular}{|c|c|c|c|c|c|c|c|c|c|c|}
\hline \multirow[t]{2}{*}{ Variety } & \multicolumn{5}{|c|}{ Yield (kg/ha) } & \multicolumn{5}{|c|}{ TKW (g) } \\
\hline & OTT & 1TT & $\begin{array}{c}\text { Reduction (\%) } \\
\text { of yield loss }\end{array}$ & 2TT & $\begin{array}{c}\text { Reduction (\%) } \\
\text { of yield loss }\end{array}$ & OTT & 1TT & $\begin{array}{c}\text { Reduction (\%) } \\
\text { of TKW loss }\end{array}$ & 2TT & $\begin{array}{c}\text { Reduction (\%) } \\
\text { of TKW loss }\end{array}$ \\
\hline Paiva & 5573 & 6066 & 8 & 8621 & 35 & 40.46 & 42.34 & 4 & 51.17 & 21 \\
\hline Roxo & 6636 & 6461 & -3 & 7393 & 10 & 44.31 & 44.67 & 1 & 48.87 & 9 \\
\hline Valbona & 7722 & 8106 & 5 & 9190 & 16 & 45.57 & 46.79 & 3 & 48.33 & 6 \\
\hline Azul & 6042 & 6828 & 12 & 9697 & 38 & 37.93 & 40.07 & 5 & 44.70 & 15 \\
\hline Galera & 7667 & 7231 & -6 & 8094 & 5 & 40.73 & 41.47 & 2 & 44.53 & 9 \\
\hline Celta & 8134 & 8012 & -2 & 9560 & 15 & 49.24 & 47.74 & -3 & 53.73 & 8 \\
\hline Core & 7620 & 7709 & 1 & 8873 & 14 & 43.53 & 45.94 & 5 & 48.03 & 9 \\
\hline Average & 7056 & 7202 & & 8775 & & 43.11 & 44.15 & & 48.48 & \\
\hline $\begin{array}{l}\text { Standard } \\
\text { deviation }\end{array}$ & 1481.81 & 1203.14 & & 1074.47 & & 4.6 & 3.71 & & 3.71 & \\
\hline CV (\%) & 21.00 & 16.71 & & 12.24 & & 10.67 & 8.40 & & 7.65 & \\
\hline Signif. TT & $\star \star \star ~$ & & & & & $* * *$ & & & & \\
\hline Signif. Var. & $* * *$ & & & & & $* * *$ & & & & \\
\hline Signif TT X Var. & $* * *$ & & & & & $* * *$ & & & & \\
\hline
\end{tabular}

stand for significant at the $0.1 \%$ level of probability

Table 4: Yield (kg/ha) and TKW (g), and corresponding gains between treatments (0/TT, 1TT) during 2016/2017 growing season

\begin{tabular}{|c|c|c|c|c|c|c|}
\hline \multirow[t]{2}{*}{ Variety } & \multicolumn{3}{|c|}{ Yield (kg/ha) } & \multicolumn{3}{|c|}{ TKW (g) } \\
\hline & OTT & $1 \mathrm{TT}$ & $\begin{array}{l}\text { Reduction (\%) } \\
\text { of yield loss }\end{array}$ & OTT & 1TT & $\begin{array}{c}\text { Reduction (\%) } \\
\text { of TKW loss }\end{array}$ \\
\hline AZUL & 4076 & 4404 & 7 & 31.95 & 34.91 & 8 \\
\hline PAIVA & 3463 & 3831 & 10 & 31.55 & 33.62 & 6 \\
\hline VALBONA & 3043 & 3438 & 11 & 30.61 & 34.03 & 10 \\
\hline CELTA & 4313 & 4003 & 8 & 37.27 & 38.20 & 2 \\
\hline CORE & 3204 & 3762 & 15 & 37.47 & 40.51 & 8 \\
\hline Average & 3620 & 3888 & & 33.77 & 36.25 & \\
\hline Standard deviation & 551.96 & 353.84 & & 3.32 & 2.98 & \\
\hline CV (\%) & 15.25 & 9.10 & & 9.84 & 8.23 & \\
\hline
\end{tabular}


leaves and ear level, except for Galera. Valbona and Celta responded positively to a single fungicide application.

The disease severity at Valbona and Celta was controled with one treatment, but with a second fungicide aplication, yield increased $11 \%$ and $15 \%$, respectively and TKW increased $3 \%$ and $8 \%$, respectively (Table III). For remaining genotypes it is reasonable to apply fungicide twice.

Due to weather conditions during 2016/2017 growing season, this one was characterized by the non-occurrence of P. striiformis. However, the trial was sown and a fungicide treatment was done in the event of controlling infections that could occur later. The analysis of varieties agronomic behaviour (Table IV) allowed to infer that yield was lower, which could be explain by the late sowing (10 January), resulting in a shorter crop phenological cycle. The gains obtained from the treatment were not related with disease control but possibly with the "stay green" effect (sin. "antiaging effect”) caused by the fungicide.

\section{CONCLUSIONS}

In this study, wheat varieties showed variation in resistance reaction, ranging from susceptibility to slow rusting towards the different fungus virulence. For the susceptible cultivars or in an epidemic situation, two spray applications are recommended for yield loss reduction, thereby increasing total production per unit area; when genotypes had a slow rusting/tolerance behaviour towards the fungus agressivity, one foliar application at GS34 was required to protect green leaf area until the onset of adult plant resistance (APR), which starts around ear emergence.

Considering that the relationship between disease scoring and yield is not straightforward and that, additionally, the onset rust epidemic will be distinctive in different years, it is possible to conclude that the requirement for fungicide sprays will depend not only on the carry over of rust inoculum in the crop, but also of the pathotypes (races/ strains) of $P$. striiformis occurring in a region, the crop growth stage at time of symptom appearance and on variety level of resistance. It is important to note that fungicides do not increase the yield potential of wheat varieties, but have the capacity to overcome the risk of losses resulting from rust and perhaps to protect the leaf area increaseing "stay green" and consequently photosynthetic rate.

\section{REFERENCES}

Ali, S., Shah, S., Khalil, I., Raman, H., Maqbool, K., Ullah, Ali, S., S. Shah, I. Khalil, H. Raman, K. Maqbool and W. Ullah. 2009. Partial resistance to yellow rust in introduced winter wheat germplasm at the north of Pakistan. Austr. J. Crop Sci. 3(1): 37-43.

Allen-Stevens, T. 2017. Yellow Rust - The Quest to Quell the Shapeshifter. Crop Production Magazine. Available from: http:// www.cpm_magazine.co.UK/about.us.

Bancal, M. O., C. Robert and B. Nery. 2007. Modelling wheat growth and yield losses from late epidemics of foliar diseases using loss of green área per layer and pre-anthesis reserves. Ann. Bot. 100: 777-789.

Chen, X. M. 2005. Epidemiology and controle f stripe rust (Puccinia striiformis f. sp. tritici) on wheat. Can. J. Plant Pathol. 27: 314-337.

Gangwar, O. P., K. Subodh, S. C. Bhardwarj, P. Prasad, H. Khan, S. Savadi and S. K. Sharma. 2017. Detection of new Yr1-virulences in Puccinia striiformis f. Sp. Tritici population and its sources of resistance in advance wheat lines and releasead cultivars. Indian Phytopathol. 70(3): 307-314.

Hodson, D. 2015. Increasing Risk of Stripe (yellow) Rust Outbreaks North Africa to South Asia. Available from: http://www. rusttracker. cimmyt.org.

Hovmoller, M. S., J. Rodriguez-Algaba. T. Thach. A. Justesen and JG. Hansen. 2017. Report of Yellow Rust Races, 2016: Global Rust Conference Center. Denmark. Available from: http://www. wheatrust.org.

Hovmoller, M. S., S. Walter, R. Bayles, A. Hubbard, K. Flath, N. Sommerfeldt, M. Leconte, P. Czembor, J. Rodriguez-Algaba, T. Thach, J. G. Hansen, P. Lassen, A. F. Justensen, S. Ali and C. Vallavieille-Pope. 2016. Replacement of the European wheat yellow rust population by new races from the centre of diversity in the near-Himalayan region. Plant Pathol. 65: 402-411.

Hussain, M., M. A. Khan, Y. Ali, M. M. Javaid, B. Iqbal, M. Nasir, W. Sabir and F. Muhammad. 2017. Wheat breeding for durable rust resistance and high yield potential in historical prospective and current status. Adv. Zool. Bot. 5(4): 55-63.

Laetitia, W., S. Savary, and J. Yuen. 2017. Multiscale phenotyping and decision strategies in breeding for resistance. Trends Plant Sci. 1524: 1-13.

Peppler, S., M. J. Gooding, K. E. Ford and R. H. Ellis. 2005. A temporal limit to the association between flag leaf life extension by fungicides and wheat yields. Eur. J. Agron. 22: 363-373.

Perlyannan, S., R. J. Milne, M. Figueroa, E. S. Lagudah and P. N. Dodds. 2017. An overview of genetic rust resistance from broad to specific mechanisms. PLoS Pathog. 13 (7): 1-4.

Qamar, M., S. D. Ahmad and M. Asif. 2012. Determination of levels of resistance in Pakistani bread wheat cultivars against stripe rust (Puccinia striiformis) under field conditions. Afr. J. Agric. Res. 7(44): 5887-5897.

Rodriguez-Algaba, J., C. K. Sörensen, R. Labouriau, A. F. Justesen and M. S. Hovmöller. 2017. Genetic diversity within and among aecia of the wheat rust fungus Puccinia striiformis on the alternate host Berberis vulgaris. Fungal Biol. 121: 541-549.

Safavi, A. S. 2015. Effects of yellow rusto $n$ yield of race-specific and slow rusting resistant wheat genotypes. J. Crop. Prot. 4(3): 395408.

Sajid, A., J. Enjalbert, P. Gladieux, A. F. Justensen, M. Hovmöller and C. Vallavieille-Pope. 2015. Worldwide Spread of Wheat Yellow Rust From the Centre of Diversity in Himalayas. Proceedings of $14^{\text {th }}$ International Cereals rusts and Powdery Mildews Conference. Helsingh, Denmark, p. 19.

Sajid, A., J. Rodriguez-Algaba, T. Thach, C. K. Sörensen, J. G. Hansen, P. Lassen, K. Nazari, D. P. Hodson, A. F. Justesen and M. S. Hovmöller. 2017. Yellow rust epidemics worldwide were 
caused by pathogen races from divergente genetic lineages. Front. Plant. Sci. 1057: 1-14.

Solh, M., K. Nazari, W. Tadesse and C. R. Wellings. 2012. The Growing Threat of Stripe Rust Worldwide. BGRI, Technical Workshop. Beijing, China, pp. 1-9.

Sorensen, C. K., M. Hovmöller, M. Leconte, F. Dedryer and C. Vallavieille-Pope. 2014. New races of Puccinia striiformis found in Europe reveal race specificity of long-term effective adult plant resistance in wheat. Phytopathology. 104: 1042-1051.

Stubbs, R. W. 1985. The cereal rusts. In: Roelfs, A. P., W. Bushnell. (Eds), Diseases, Distribuition, Epidemiology and Control. Vol. 2. Academic Press, London, U K, pp. 61-101.

Stubbs, R. W., J. M. Prescott, E. E. Saari and H. J. Dubin. 1986. Cereal Disease Methodology Manual. Centro Internacional de Mejoramiento de Maiz y Trigo (CIMMYT), México, pp. 20-24.
Vallavieille-Pope, C., S. Ali, M. Leconte, J. Enjalbert, M. Delos and J. Rouzet. 2012. Virulence dynamics and regional struturing of Puccinia striiformis f. sp. Tritici in France between 1984 and 2009. Plant Dis. 96(1): 131-140.

Vergara-Diaz, O., S. Kefauver, A. Elazab, M. T. Neto-Taladriz and J. L. Araus. 2015. Grain yield losses in yellow-rusted durum wheat estimated using digital and conventional parameters under field conditions. Crop J. 3: 200-210.

Walter, S., A. Sajid, E. Kemen, K. Nazari, B. A. Bahri, J. Enjalbert, J. G. Hansen, J. Brown, T. Sicheritz-Ponten, J. Jones, C. Vallavieille-Pope, M. Hövmoller and A. F. Justensen. 2016. Molecular markers for tracking the origin and worldwide distribution of invasive strains of Puccinia striiformis. Eco. Evol. 6(9): 2790-2804.

Zadocks, J. C. 1972. Methodology of epidemiological research. Ann. Ver. Phytopathol. 10: 253-76. 